\title{
Evaluation of the quality of surface finish of messassa wood for three types of varnishes.
}

\author{
Narciso Fernando Bila ${ }^{\mathrm{a}^{*} \oplus \text {, Rosilani Trianoski }}{ }^{\mathrm{b}}$, Andrade Fernando Egas $^{\mathrm{a} *}{ }^{*}$, Setsuo Iwakiri ${ }^{\mathrm{b}}$, \\ Marcio Pereira da Rochab ${ }^{\text {(O) }}$ \\ ${ }^{\text {a } U n i v e r s i d a d e ~ E d u a r d o ~ M o n d l a n e, ~ M o c ̧ a m b i q u e ~}$ \\ ${ }^{\mathrm{b}}$ Universidade Federal do Paraná, Brasil \\ ${ }^{*}$ Autor correspondente (bila.narciso@gmail.com)
}

\section{N F O}

\section{Keywords}

Brachystegia

spiciformis

Julbernardia globiflora

furniture and frames

production

lesser-used species

coating products

\begin{abstract}
A B S T R A C T
The aim of this study was to evaluate the performance of the messassa wood Brachystegia spiciformis and Julbernardia globiflora for three types of finishing products for use in the furniture and frames industries. Coating performance was assessed by adhesion strength, impact deformation resistance, abrasiveness, gloss and overall color variation tests based on technical standards. Copal painting application was higher for gloss, adhesion and lower abrasiveness compared to water based and polyurethane. The impact deformation was higher for polyurethane than water-based and copal for both species. The darkening of wood for Brachystegia spiciformis and a slight lightening of wood by Julbernardia globiflora characterize the overall color variation after application of the coating products. According to these results, the varnishes can be used to add value to the messassa wood as a finish in solid wood furniture and frames.
\end{abstract}

\section{R E S U M O}

Avaliação da qualidade de acabamento superficial da madeira de messassa para três tipos de vernizes. O objetivo deste estudo foi avaliar o desempenho da madeira das messassas Brachystegia spiciformis e Julbernardia globiflora perante três tipos de produtos de acabamento superficial para utilização na indústria moveleira e de molduras. Foram utilizados como acabamento o verniz Copal, verniz base de água e verniz poliuretano. $\mathrm{O}$ acabamento foi avaliado através de ensaios de resistência à aderência (pull-off), impacto, abrasividade, brilho e medição de variação da cor com base em normas técnicas. As espécies apresentaram resultados satisfatórios nos ensaios para todos os vernizes. Houve variação da cor após a aplicação do acabamento caracterizada pelo escurecimento da madeira para espécie Brachystegia spiciformis e um ligeiro clareamento para madeira da Julbernardia globiflora. Conclui-se que os três vernizes podem ser utilizadas nestas espécies para agregação do valor da madeira como acabamento em móveis e molduras de madeira sólida. 


\section{INTRODUCTION}

Messassa is the trade name given to the Mozambican wood species Brachystegia spiciformis Benth (basic density $0.670 \mathrm{~g} / \mathrm{cm}^{3}$ ) and Julbernardia globiflora (Benth) Troupin. (basic density 0.680 $\mathrm{g} / \mathrm{cm}^{3}$ ) (Bila et al., in press) both belonging to the Fabaceae family. The species has the greatest commercial volume, which is estimated at around 360 million cubic meters, equivalent to $46 \%$ of the total existing commercial volume in the country (Magalhães, 2017). However, the messassa wood are currently used for low value applications such in civil construction as props and charcoal production in rural areas. There are several reasons that may explain this trend, such as lack of tradition in their use, technological knowledge and adequate industrial infrastructure, among others (DNTF, 2017). However, the Mozambican wood and furniture industry, in addition to using traditional wood species, has been exploring possibilities for the use of new and lesser-used ones, including activities to improve the quality of traded products for better fit into the increasingly competitive market.

The varnishes can add value to low valued woods or lesser used in the market giving them a desired aesthetic appearance. On the other hand, Bulian and Graystone (2009) state that with finishing application improves the aesthetics of a machined wood, provides a clean surface and protects it over time. However, the final quality of the finish depends on several elements including the application of the coating method, substrate characteristics such as porosity, chemical structure and interaction between the coating and the substrate (Ozdemir; Hiziroglu, 2007). In addition, Moura and Hernandez (2006) point out that sanding is the most commonly used operation for surface preparation before finishing, since it's function is to leveling the natural differences of wood surface, providing a homogeneous cover. Products commonly used in wood finishing are varnishes (natural or synthetic), sealers and paints. However, it is noteworthy that among the various possibilities, the most suitable type of finish for wood depends on the intended use of the final product and/or consumer preference
(Watai, 1995). The evaluation of the finishing quality applied to the wood surface is made by tests of adhesion resistance (pull-off), impact, abrasiveness and gloss (Guedes, 2011; Silva et al., 2010; Désor et al., 1999).

Wood color is also an important component of its appearance and crucial in the consumer's final decision as well as being one of the physical parameters of quality assessment (Jankowskya and Ozakiewicz, 2014; Barcik et al., 2015; Dzurenda, 2018). This property should be incorporated into the planning, aiming at the technological characterization of wood (Mori et al., 2005). Additionally, among the organoleptic properties, color is the characteristic that presents the highest subjectivity, as it is directly related to the psychophysical sensitivity of the observer (Zenid and Ceccantini, 2007). Therefore, depending on the specifications of the finishing product, natural wood color variation may occur, influencing the preference of the furniture or frames by the consumer.

Considering that no surface finishing studies were found in messassas wood, this work aims to generate information regarding the behavior of these species when submitted to surface finishing products, such as varnishes seeking to enhance and promote them in the furniture and frame industry.

\section{MATERIAL AND METHODS}

The wood species used in this study comes from the Miombo forest, located in Zambezia province, central Mozambique at coordinates WSG84 17 $7^{\circ} 18^{\prime}$ $22^{\prime \prime} \mathrm{S}, 37^{\circ} 38^{\prime} 26^{\prime \prime} \mathrm{W}$. From randomly selected heartwood pieces previously used in machining tests (planing, shaping, milling, tearing and boring) and with a moisture content of $12 \pm 2 \%, 18$ samples free of defects such as knots, rot and cracks were produced for finishing application. The samples had dimensions of $230 \mathrm{~mm}$ in length, $10 \mathrm{~mm}$ in thickness and width ranging from 100 to $120 \mathrm{~mm}$. Three types of varnishes were used for finishing (Table 1) and acquired in the local market. Exceptionally for PU varnish, the manufacturer recommends first applying the bottom (sealer) before the varnish and the brushing in a crosswise direction.

Table 1 - Specifications of used coating product by the manufacturer

\begin{tabular}{lcccc}
\hline Propertie/coating & Water based & Copal & Polyurethane & Sealer \\
\hline Manufacturer & Sayerlack & BASF/Suvenil & Sayerlack & Sayerlack \\
Density g.cm ${ }^{-3}$ & $1.03 \pm 0.02$ & $0.86-0.90$ & $1.00 \pm 0.02$ & $1.02 \pm 0.02$ \\
Solid content (\%) & $32.0 \pm 2$ & $33-37$ & $43.86 \pm 2$ & $60.8 \pm 2$ \\
Viscosity (Cp.s) & $20 \pm 2 \mathrm{~s} \mathrm{CF} 4$ & - & $28.2 \mathrm{~s}$ CF4 & $60 \pm 5 \mathrm{~s}$ CF6 \\
\hline
\end{tabular}

Where: $\mathrm{CF}$ - ford cup; $\mathrm{Cp}$ - Centipoise 


\section{Surface Preparation and Finishing Application}

The preparation and application of the varnishes complied with the manufacturer's requirements. It is noteworthy that prior to application of the finishing product, the lumber for sample production were subjected to sequential sanding (in the grain direction) with 100,150 and 180 grit size sandpapers in industrial production line. For this purpose a band sander was used at a feed speed of $8 \mathrm{~m} \cdot \mathrm{min}^{-1}$ and surface pressure $0.03 \mathrm{MPa}$. Three passes were performed at a cutting thickness of $0.5 \mathrm{~mm}$ each.

The spread rate in all finishing products was 180 g. $\mathrm{m}^{-2}$ estimated by an analytical scale. Two coats were applied to each varnish by a non-sanding foam roller between the coats. After application of the varnish, the samples remained at room temperature $(20 \pm 2){ }^{\circ} \mathrm{C}$ and relative humidity of $(65 \pm 5) \%$ for a period of 7 days for total cure of the varnish.

\section{Performance of tests}

After curing the varnish, the gloss, adhesion, abrasiveness, impact deformation and overall color variation tests were performed. The brightness test consisted of reading the values of light intensity range provided by the Glossmeter device at $60^{\circ}$ angle. Ten (10) readings per sample were taken for each varnish and specie parallel to the grain, a procedure suggested by ABNT 14535 (2008).

The pull-off test (adhesion) was performed according to ASTM D 4541 - 17 (2017) method E. Iron cylinder of $20 \mathrm{~mm}$ in diameter were glued to the coated sample by transparent two-component epoxy adhesive and cure time of 48 hours. After curing of adhesive, a circular groove was made around the cylinder to prevent the spread of faults outside the test area. The pull-off test involves withdrawal of cylinders upwards vertically in the opposite direction from the position of the sample at a rate of $0.20 \mathrm{MPa}_{\mathrm{s}}{ }^{-1}$. Three measurements were taken per sample for each varnish. This method involves measuring of the maximum adhesion strength of a coating that leads to the detachement of cylinder from the coated surface. The adhesion strength of each sample reached at rupture was recorded on the equipment display in MPa.

The abrasiveness test was performed using a Texcontrol TC 110 abrasimeter. The equipment consisted of CS-17 wheels, $1000 \mathrm{~g}$ adjustment load and $60 \mathrm{rpm}$ (revolutions per minute). The wear rate was determined by the ratio of mass loss difference (milligrams) before and after abrasion of the fin- ished surface to the number of abrasion cycles performed until the wood substrate was reached, i.e., until visually verified along the entire circle worn by the wheels the complete removal of the coating. Samples were weighed on an analytical scale of $0.0001 \mathrm{~g}$ precision. The samples (three per varnish and specie) were dimensioned at $100 \times 100 \mathrm{~mm}$ in each varnish based on ABNT 14535 (2008) standard.

The impact strength test of the film was carried out by dropping a $19 \mathrm{~mm}$ diameter steel ball at a height of 2 meters over the sample. Then, the damage caused to the finishing film was evaluated in a 10x magnifying glass according to the grading scale contained in NBR 14535 (2008), which ranges from 5 to 1 . The degree of impact with value 5 (five) corresponds to the absence of impact, that is, no cracking or cracking on the coated wood surface. In turn, the impact degree with a value of 1 (one) is assigned when more than $25 \%$ of the finishing film is removed from the impact area. Six (6) samples per varnish and specie were used with three repetitions for each sample. This test simulates the impact of small objects falling on the finishing film.

Color variation analysis were performed using the CIELAB method 1976 (Commission International de L'Eclairage) before and after application of the coating with the aid of the $10^{\circ}$ observation angle color spectrophotometer and standard illuminant $\mathrm{D}_{65}$. The color measurement was made at three (different) points of the coated surface of each sample. Eighteen (18) measurements were performed by varnish. The colorimetric parameters obtained were $L^{*}$ (luminosity), $a^{*}$ (red-green axis coordinate) and $b^{*}$ (blue-yellow axis coordinate). The color variation $(\Delta \mathrm{E})$ due the coating was determined by the following equation:

$$
\Delta E=\sqrt{(\Delta L *)^{2}+(\Delta a *)^{2}+(\Delta b *)^{2}}
$$

Where: $\Delta \mathrm{E}$ - is the total color variation on the sample surface; $\Delta L^{*}, \Delta a^{*}$ and $\Delta b^{*}$ - average variation of the $L^{*}, a^{*}$ and $b^{*}$ coordinates on the sample surface before and after finishing application (example: $\Delta L^{*}=L^{*}$ uncoated $-L^{*}$ coated).

The classification of the overall color variation $(\Delta E)$ on the coated surface was based on assessment guidelines by Cividini et al. (2007) (Table 2). 
Table 2 - The criteria to assess the overall color variation $(\Delta E)$ on Brachystegia spiciformis and Julbernardia globiflora wood

\begin{tabular}{cl}
$0.2<\Delta E$ & Invisible change \\
$0.2<\Delta E<2$ & Small changes \\
$2<\Delta E<3$ & Changes visible by high quality filter \\
$3<\Delta \mathrm{E}<6$ & Changes visible by medium quality \\
& filter \\
$6<\Delta E<12$ & Distinct color changes \\
$\Delta E>12$ & A different color \\
\hline
\end{tabular}

\section{Date analysis}

The data were submitted to Bartlett test to verify the homogeneity of the variances. Then, an analysis of variance (ANOVA) and determination of average values of each property were performed. The Tukey test were used to compare the average values of finishing products and t-student test for comparisons between the species both at 5\% significance level in order to verify the best performance of the applied finishing product and the species.

\section{RESULTS AND DISCUSSION}

\section{Gloss}

The average gloss obtained from the coated samples of B. spiciformis and J. globiflora were mostly classified as semi-gloss. Exceptionally samples finished with copal varnish for species B. spiciformis this property was classified as bright, witnessed by the highest average value (Table 3 ). This exception may have been caused by the intrinsic characteristic of the wood in presenting light color associated with the inherent gloss characteristics of the copal product when compared to water based and polyurethane varnishes. In addition, according to the manufacturer water-based and polyurethane varnishes are satin-like with semi-glossy characteristics while the copal is glossy which justifies the (statistically significant) difference in gloss between the finishing products as well as between species.

Table 3 - Average gloss of the varnishes applied to the wood of Brachystegia spiciformis and Julbernardia globiflora

\begin{tabular}{cccc}
\hline \multirow{2}{*}{ Species } & \multicolumn{3}{c}{ Varnish gloss (GU) } \\
\cline { 2 - 4 } B. spiciformis & Water based & Copal & Polyurethane \\
& $34.92 \mathrm{Ca}$ & $73.85 \mathrm{Aa}$ & $45.18 \mathrm{Bb}$ \\
J. globiflora & $(4.5)$ & $(2.7)$ & $(6.7)$ \\
& $32.27 \mathrm{Cb}$ & $66.68 \mathrm{Ab}$ & $52.85 \mathrm{Ba}$ \\
\hline
\end{tabular}

Means followed by the same lowercase letter in the column (t-student test) and uppercase in the row (Tukey test) do not differ statistically at 5\% significance level; Value in parentheses is the coefficient of variation in percentage; GU - gloss unit.

The average gloss for both species had a decreasing trend in the order copal coating, followed by polyurethane and lastly water based (Table 3). Namikata (2016) also reported similar results to this observed trend in the present study in the evaluation of the brightness in Cryptomeria japonica wood. Differently, studies comparing the gloss of the water based with synthetic and nitrocellulose coating (Çakicier et al., 2011) and polyurethane (Budakçi and Sonmez, 2010) found a higher gloss value than that of water based, caused by the formulation of the varnishes used. It is noted that the varnishes are formulated in order to obtain the desired gloss for the consumer's preference, and for each type of varnish (whether water based, polyurethane or copal), a variant of matte gloss can be found, satin, semi-gloss or even glossy.

When comparing the performance of each species (Table 3), it is noticeable that B. spiciformis showed greater brightness in the wood when applying water based and copal varnish, while the application of polyurethane varnish was the one that provided higher brightness in relation to J. globiflora species.

\section{Adhesion strength}

The results of the finish adherence test showed a range of variation from 2.60 to $5.97 \mathrm{MPa}$ between varnishes as well as between species (Table 4). In turn, it is also observed that both in the species $B$. spiciformis and J. globiflora, copal and polyurethane varnishes had average values statistically equal and superior to water-based varnish. This result is associated with the specifications of each finishing product used, in which the water based varnish compared to the others, had a lower solids content and viscosity as shown in Table 1 . 
Tabela 4 - Average of adhesion strength in adhesion tests of the surface finish on wood of Brachystegia spiciformis and Julbernardia globiflora, under three types of varnishes.

\begin{tabular}{|c|c|c|c|c|}
\hline \multirow{2}{*}{ Varnish } & \multicolumn{3}{|c|}{ Adhesion strength (MPa) } & \multirow{2}{*}{$\mathrm{CV}(\%)$} \\
\hline & Minimum & Average & Maximum & \\
\hline \multicolumn{5}{|l|}{ B. spiciformis } \\
\hline Water based & 2.60 & $2.83 \mathrm{~b}$ & 3.47 & 13.10 \\
\hline Copal & 3.68 & $4.16 \mathrm{a}$ & 4.58 & 7.32 \\
\hline Polyurethane & 3.46 & $3.86 \mathrm{a}$ & 4.33 & 9.80 \\
\hline \multicolumn{5}{|l|}{ J. globiflora } \\
\hline Water based & 3.90 & $3.41 \mathrm{~b}$ & 4.50 & 4.63 \\
\hline Copal & 3.47 & $4.17 \mathrm{a}$ & 5.72 & 19.61 \\
\hline Polyurethane & 3.11 & $4.16 \mathrm{a}$ & 5.97 & 9.17 \\
\hline
\end{tabular}

Averages followed by the same letter between varnishes within the specie do not differ statistically from each other by Tukey test at $5 \%$ of significance level; CV - coefficient of variation.

In a similar study, Souza et al. (2011) reported in solid wood a better adhesion of solvent based coating compared to water based, having also stated that it was the result of the type of varnish and the specificity of it's formulations. In contrast, Hazir and Koc (2019) reported for MDF panels better performance of water based varnish compared to solvent based with adhesion strength values ranging from 2.98 to $3.47 \mathrm{MPa}$ and 2.06 to $2,31 \mathrm{MPa}$, respectively. It is important to emphasize that the difference in results between different studies might be due to the intrinsic characteristics of the wood and/or derived products evaluated, the incompatibility of the wood with the product or the application or final assessment methodology, among others.

Comparison of species performance under coating products shows statistically equal adhesion strength only when finished with the copal (Figure $1)$.

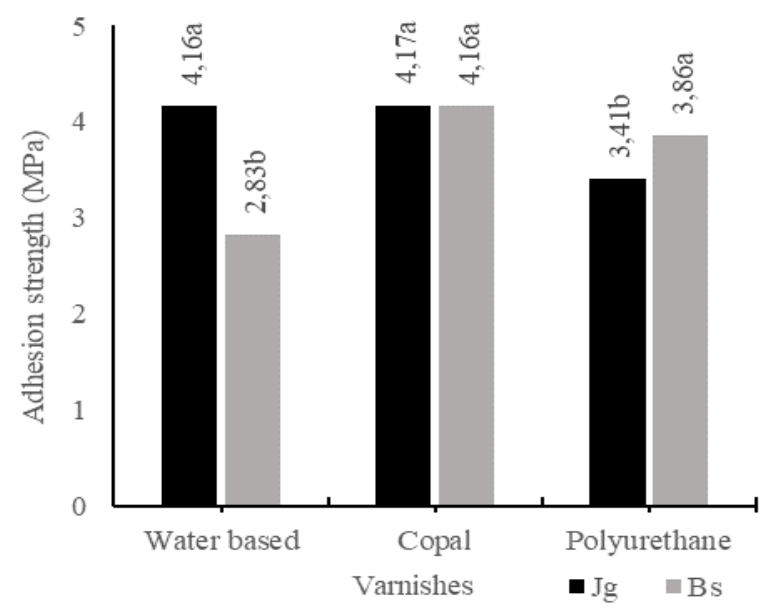

Where: Averages followed by the same letter between species within the varnish do not differ statistically from each other by t-student test at $5 \%$ of significance level.

Figure 1 - Adhesion strength variation of the coatings on Brachystegia spiciformis (Bs) and Julbernardia globiflora $\left(J_{S}\right)$ wood.
In turn, (based on Figure 1) it is observed that the species J. globiflora had higher adhesion strength compared to the species B. spiciformis when finished with water-based and polyurethane varnishes. This result may probably be due to the anatomy of the wood species as a whole but also to the high content of extractives (in particular) of the species B. spiciformis $(19,63 \%)$ in relation to J. globiflora $(16,66 \%)$ as reported by Bila et al. (2019, in press). Ghofrani et al. (2016) state that the effect of the extractives content in the case of the application of finishing products, is the reduction of the compatibility and the adhesion strength of the varnishes.

In this respect, considering the relevance of the film adhesion test in the evaluation of the performance of finishing products, studies that also evaluate wood samples of the species B. spiciformis and $J$. globiflora coated with the three types of varnishes and exposed to weather conditions in order to provide more comprehensive information about their adhesion strengths are demanded.

\section{Abrasiveness}

Results of the abrasion strength test are presented in Table 5. The wear rate ranged from 0.1432 to $0.3635 \mathrm{mg} / 1000$ cycles and was statistically equal across species for all varnishes. Comparing the varnishes in each species, there is a tendency of higher wear rate in the water-based, followed by the polyurethane and lastly the copal. However, it is found that the abrasion strength occurred in the opposite direction being higher in the polyurethane, followed by the copal and water based coating, witnessed by the larger number of abrasion cycles required to remove the film from the coated surface.

The greatest resistance to polyurethane varnish may have been due to its higher thickness of the finishing film layer. Bulian and Graystone (2009) 
point out that polyurethane varnish has some advantages such as flexibility, abrasion resistance, chemical resistance, good adhesion and fast cure when compared to water based, nitrocellulosic and copal varnishes, and for this reason they are most used in the furniture industry.

There was no statistically significant difference in the wear rate between water-based varnish and polyurethane in both species (Table 5). It is noteworthy that the abrasion resistance test assesses the gradual wear of the surface of the finish by abrasive action that can be caused by shoes, transport and movement of materials on a floor, sand, dirt, among others (Moreschi, 2005; Silva et al., 2010).

Table 5 - Abrasion strength of the varnishes applied to Brachystegia spiciformis and Julbernardia globiflora wood.

\begin{tabular}{ccccc}
\hline \multirow{2}{*}{ Varnish } & \multicolumn{2}{c}{ B. spiciformis } & \multicolumn{2}{c}{ J. globiflora } \\
\cline { 2 - 5 } & Nr. of Cycles & WR (mg/1000 cycles) & $\begin{array}{c}\text { Nr. of Cy- } \\
\text { cles }\end{array}$ & WR (mg/1000 cycles) \\
\hline \multirow{3}{*}{ Water based } & $169 \mathrm{~b}$ & $0.3635 \mathrm{Aa}$ & $265 \mathrm{~b}$ & $0.3535 \mathrm{Aa}$ \\
& $(13.25)$ & $(19.9)$ & $(17.2)$ & $(19.3)$ \\
& & & & $0.1432 \mathrm{Ab}$ \\
Copal & $195 \mathrm{ab}$ & $0.2159 \mathrm{Ab}$ & $435 \mathrm{a}$ & $(8.2)$ \\
& $(5.63)$ & $(45.2)$ & $(9.6)$ & $0.2733 \mathrm{Aa}$ \\
Polyurethane & $221 \mathrm{a}$ & $0.3538 \mathrm{Aa}$ & $443 \mathrm{a}$ & $(24.99)$ \\
\hline
\end{tabular}

Means followed by the same lowercase letter in the column (Tukey test) and uppercase in the row (t-student test) do not differ statistically at 5\% of significance level; WR - wear rate; Value in parentheses is the coefficient of variation, $\mathrm{Nr}$. - Number.

\section{Impact deformation resistance}

The results of the impact test demonstrate that there was no significant difference between water based and copal varnish as well as between species in all varnishes. In turn, the polyurethane varnish had lower average impact values compared to the other varnishes in both species (Table 6).

Table 6 - Average impact strength of varnishes on wood of Brachystegia spiciformis and Julbernardia globiflora

\begin{tabular}{cccc}
\hline \multirow{2}{*}{ Specie } & & Varnish & \\
\cline { 2 - 4 } B. spiciformis & Water based & Copal & Polyurethane \\
& $5.0 \mathrm{Aa}$ & $5.0 \mathrm{Aa}$ & $4.1 \mathrm{Ba}$ \\
J. globiflora & $(0.0)$ & $(0.0)$ & $(8.4)$ \\
& $4.9 \mathrm{Aa}$ & $5.0 \mathrm{Aa}$ & $3.8 \mathrm{Ba}$ \\
& $(2.3)$ & $(0.0)$ & $(4.6)$ \\
\hline
\end{tabular}

Means followed by the same lowercase letter in the column (t-Student test) and uppercase in the row (Tukey test) do not differ statistically at $5 \%$ of significance level

According to ABNT 14535 (2008) standard, the impact grade values is inversely proportional to the presence of cracks in the area impacted by the sphere. The polyurethane were attributed the lower average grade (4) in both species (Table 6) compared to the other finishing products varnish, which means that, this varnish presented cracks around the impact area. This result is owing to the thick film layer that the polyurethane varnish presents due to its higher solids content, associated with the application of the sealing bottom, as illustrated in Table 1. Namikata (2016) also reported less resistance to impact on the polyurethane varnish in relation to nitrocellulosic varnishes, water-based and copal on the wood of Cryptomeria japonica. In turn, Erdinler (2019) analyzing the performance of two MDF panel finishing products obtained greater resistance to the impact on polyurethane varnish (4 and 5) when compared to cellulosic varnish (grades 2 and 3). It is noteworthy that, the variation in the results among different studies may occur depending on the composition of the finishing product, substrate and even the application method. 


\section{Color variation}

The colorimetry parameters of uncoated and coated wood surface of B. spiciformis and J. globiflora showed a wide range of variation of the basic parameters $L^{*}, a^{*}, b^{*}$ and $\Delta \mathrm{E}$ (Table 7). It is observed that with the application of the varnishes on B. spiciformis wood the brightness value $\left(L^{*}\right)$ was decreasing significantly compared to the uncoated wood and therefore the varnishes caused a darkening in the natural color of the wood whose ranged from 39.64 to 46.14. Copal varnish resulted in greatest darkening of the wood. There is no statically significant difference between the effect of water based and polyurethane varnish in the brightness. The luminosity value $L^{*}(53.92)$ of uncoated wood of the species B. spiciformis is within the light range of thirty tropical wood species reported by Silva et al. (2017). It is noticeable that the value of the parameter $L^{*}$ has a direct proportionality with the clarity of a particular material and/or substrate to be evaluated. According to Camargos and Gonçalez (2001), wood is considered dark if the $\mathrm{L}^{*}$ value is less than or equal to 56 .

Table 7 - Evaluation of overall color variation for coated and uncoated wood of Brachystegia spiciformis and Julbernardia globiflora.

\begin{tabular}{ccccccc}
\hline \multirow{2}{*}{ Specie } & \multirow{2}{*}{ Varnishes } & \multicolumn{3}{c}{ Color coordenates } & \multicolumn{2}{c}{ Total color variation } \\
\cline { 3 - 7 } & Uncoated & $53.92 \mathrm{a}$ & $12.01 \mathrm{bc}$ & $20.46 \mathrm{c}$ & - & Evaluation \\
\hline \multirow{3}{*}{$\begin{array}{c}\text { Brachystegia spic- } \\
\text { iformis }\end{array}$} & Water based & $43.28 \mathrm{ab}$ & $17.16 \mathrm{a}$ & $25.89 \mathrm{ab}$ & 13.0 & $\begin{array}{c}\text { Different color } \\
\end{array}$ \\
& Copal & $39.64 \mathrm{c}$ & $17.91 \mathrm{a}$ & $27.81 \mathrm{a}$ & 17.1 & $\begin{array}{c}\text { Different color } \\
\text { Polyurethane }\end{array}$ \\
& $46.14 \mathrm{ab}$ & $15.29 \mathrm{ab}$ & $27.57 \mathrm{a}$ & 11.0 & $\begin{array}{c}\text { Distinct color } \\
\text { changes }\end{array}$ \\
\hline \multirow{2}{*}{$\begin{array}{c}\text { Julbernardia } \\
\text { globiflora }\end{array}$} & Uncoated & $38.38 \mathrm{c}$ & $10.06 \mathrm{~d}$ & $19.01 \mathrm{~d}$ & - & - \\
& Water based & $44.61 \mathrm{ab}$ & $11.37 \mathrm{c}$ & $20.47 \mathrm{c}$ & 5.7 & Changes visible by \\
& Copal & $40.92 \mathrm{ab}$ & $11.49 \mathrm{c}$ & $21.90 \mathrm{bc}$ & 3.8 & medium quality filter \\
\hline
\end{tabular}

Means followed by the same letter within the same column per specie do not differ statistically by Tukey test at 5\% of significance level.

The parameters $a^{*}$ and $b *$ increased significantly with the application of the varnishes meaning thereby increasing the influence of the red-green and blue-yellow axis respectively. The increase in the red pigmentation $\left(\mathrm{a}^{*}\right)$ may also explain the wood darkening after applying the varnishes. In different circumstances, Paula et al. (2020) reported that the combination between the high values of $L^{*}$ coordinate and the low values of coordinate $a^{*}$ may still be indicative of the low percentage of extractives present in the wood. However, for the species under study whose extractive contents are high, typical of tropical wood, perhaps a more in-depth chemical analysis could help to understand the fact.

For the species J. globiflora, the luminance value $L^{*}$ had a statically significant increase only in the water-based (44.61) and copal (40.92) varnishes lightening the wood to a certain extent in relation to its natural color. The application of polyurethane coating caused a statistically non-significant change in surface brightness (Table 6 ). The parameters $a^{*}$ and $b^{*}$ show similar behavior and are increasing with the application of the varnishes as observed in B. spiciformis wood.

The overall color variation $(\Delta \mathrm{E})$ parameter showed that B. spiciformis wood had a considerable color change. In turn, for J. globiflora wood the color variation is visible with the medium quality filter (Table 6) which assumes that the natural color of this wood has had a subtle changed with the application of the varnishes. Also based on Table 6, it is noted that $J$. globiflora has a dark natural color $\left(L^{*}=38.38\right)$ compared to B. spiciformis $\left(L^{*}=\right.$ 53.92).

Figure 2 shows the overall color variation $(\Delta \mathrm{E})$ for the three types of coating products. The total color variation of wood after coating is characterized by darkening for B. spiciformis and a slight lightening of wood for J. globiflora. This color shade difference may have been influenced by the intrinsic anatomy of the species as well as the characteristics of the finish products in interaction with wood chemical components (Yamamoto et al. 2007).

From figure 2, the polyurethane coating caused the lowest color variation of the wood for both specie. The water based coating had an intermediate color variation value in species $B$. spiciformis. For $J$. globiflora species the intermediate color variation was verified in the copal coating. It may be 
noted that, the effects of these finishing products on the quality of the wood of the messassas will be inferred in the end by the consumer since it is based on the color that it is classified aesthetically as acceptable or not.

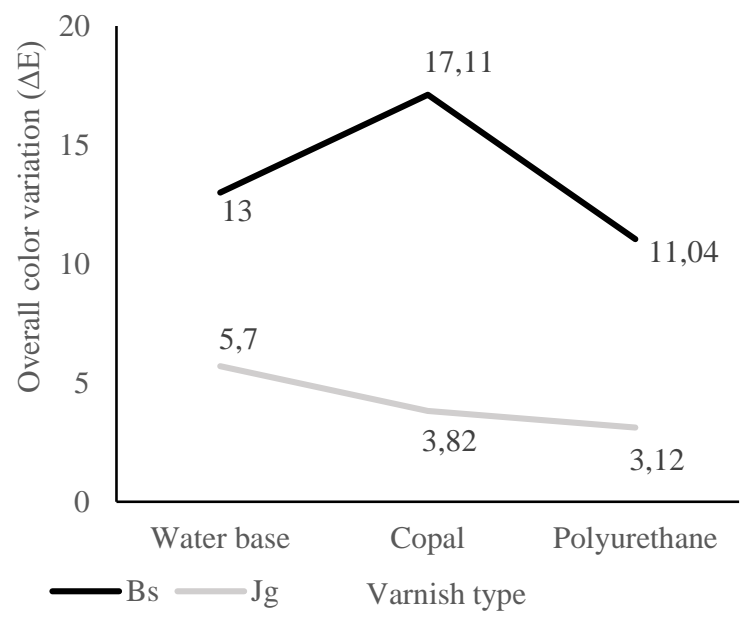

Figure 2 - Overall color variation $(\Delta \mathrm{E})$ of coated surface of B. spiciformis (Bs) and J. globiflora $(\mathrm{Jg})$ wood.

\section{CONCLUSIONS}

From the results obtained, it is concluded that:

- The gloss of the surface finished with the water based and polyurethane varnish used in the wood of B. spiciformis and $J$. globiflora were classified as semi-gloss. The copal varnish resulted in bright gloss;

- The impact resistance was equal for water based and copal varnish as well as between species. Polyurethane varnish was the lesser resistant to impact;

- Copal and polyurethane varnishes presented equal adhesion strength in both species. The water based varnish had the lowest adhesion;

- Polyurethane varnish showed the highest wear resistance;

- The used coating products induce a considerable color variation mainly for $B$. spiciformis in relation to J. globiflora;

- The performance of the three varnishes was satisfactory and can be used in the species studied to add value to the wood as a finish on furniture and solid wood frames.

\section{REFERENCE}

Associação Brasileira de Normas Técnicas. NBR 13528: Revestimento de paredes e tetos de argamassas inorgânicas -
Determinação da resistência de aderência à tração. Rio de Janeiro, 1995.

Babiak M, Kubovský I, Mamonov M. Color space of the selected doestici species, In: Interaction of wood with various forms of energy, Technical University of Zvolen, Zvolen, Slovakia, p.113-117, 2004.

https://doi.org/10.1080/20426445.2019.1693086

Barcík S, Gasparík M, Razumov EY. Effect of temperature on the color change of wood during thermal modification. Cell. Chem. Techonol. v.49, n.9/10, p.789-798, 2015

Bila NF, Trianoski R, Egas AF, Iwakiri S, Mussana AF, Rocha MP. Bonding quality of Brachystegia spiciformis and Jubernardia globiflora, lesser-used wood species from Mozambique. In press.

Budakçi M, Sonmez A. Determining adhesion strength of some wood varnishes on different wood surfaces. Journal of the Faculty of Engineering and Architecture of Gazi University, v.25, n.1, p.111-118, 2010.

Bulian F, Graystone JA. Wood Varnishes: Theory and Practice. Elsevier Science Ltd.: Amsterdam, p. 320, 2009.

Çakicier N, Korkut, S, Güler FD. Effects of heating treatment on some of the physical properties of varnish layers applied on various wood species. African Journal of Agricultural Research, v.10, n.9, p.1578-1585, 2011.

Camargos JAA, Gonçalez JC. A colorimetria aplicada como instrumento na elaboração de uma tabela de cores de madeira. Brasil Floresta, v.71, p.30-41, 2001.

Cividini R, Travan L, Allegretti O. White beech: A tricky problem in the drying process. In: International Scientific Conference on Hardwood Processing, Québec city, Canada, p.135-140, 2007.

Cox RM. Building an industrial wood finish. Madison: Forest Products Society, p.11, 2003.

Désor U, Krieger S, Apitz G, Kuropka R. Water-borne acrylic dispersions for industrial wood varnishes. Surface Varnishes International, v.10, p.488-496, 1999.

Direção Nacional de Terras e Florestas (DNTF). Exploração Sustentável da Madeira em Moçambique. Maputo, 16p, 2017.

Dzurenda, L. The shades of color of Quercus robur L. wood obtained through the process of thermal treatment with saturated water capor. BioResources, v.13, n.1, p.1525-1533, 2018.

Erdinler ES, Koc KH, Dilik T, Hazir Z. Layer thickness performances of varnishes o MDF: Polyurethane and Cellulosic paints. Maderas. Ciencia y tecnologia, v.21, n.3, p. $317-$ 326, 2019.

https://doi.org/10.4067/S0718-221X2019005000304

Ghofrani M, Zahra F, Ashori A. Effects of extractives removal on the performance of clear varnish varnishes on boards. Journal of Composite Materials, v.50, p.30193024, 2016.

https://doi.org/10.1177/0021998315615205

Guedes JS. Estudo e optimização do acabamento de orlas em tampos de mesas escolares. Ano de obtenção: 2011. 43 p. Dissertação (Mestrado em Engenharia Química) - Setor de Engenharia Química, Universidade do Porto, Porto. 
Hazir, E, Koc KH. Evaluation of wood surface coating performance using water 3 based, solvent based and powder coating. Maderas. Ciencia y tecnologia, v.21, n.4, p.1-22, 2019.

https://doi.org/10.4067/S0718-221X2019005000404

Jankowska A, Kazakiewicz P. Influence of thermal modification of scots pine wood (Pinus sylvestris L.) on color change. Annals of warsow University of life sciences SGGW. Forestry and Wood Technology v.88, p.92-96, 2014.

Moreschi, JC. Propriedades Tecnológicas da Madeira. UFPR. 192 p. 2012.

Mori CLSO, Lima JT, Mori FA, Trugilho PF, Gonçalvez JC. Caracterização da cor da madeira de clones de híbridos de Eucaliptus spp. Cerne, v.11, n.2, p.137-146, 2005.

Moura LF, Hernández RE. Effects of abrasive mineral, grit size and feed speed on the quality of sanded surfaces of sugar maple wood. Wood Science and Technology, v.40, p. 130-136, 2006. https://doi.org/10.1007/s00226-006-0070-0

Namikata AP. Utilização da madeira de Cryptomeria japonica para a produção de painéis colados lateralmente e aplicação de acabamento superficial. Ano de obtenção: 2016. 188 p. Dissertação (Mestrado em Engenharia Florestal) - Universidade Federal de Paraná, Curitiba.

Ozdemir T, Hiziroglu S. Evaluation of surface quality and adhesion strength of treated solid wood. Journal of Materials Processing Technology, v.186, p.311-314, 2006. https://doi.org/10.1016/j.jmatprotec.2006.12.049

Paula MH, Mesquita RRS, Costa MA. Gonçalez JC, Ananias RA, Janin G. Effect of applying finishing products and sanding on the surface of marupa wood. Maderas. Ciencia y Tecnologia, v.22, n.1, p.45-50, 2020. https://doi.org/10.4067/S0718-221X2020005000105

Silva JRM, Alves JÁ, Nogueira MOG, Braga PPC. Qualificação da superfície acabada em madeiras de Eucalyptus grandis W. Hill ex Maiden, Toona ciliata $\mathrm{M}$. Roemer e Coffea arabica L. Cerne, v.16, p.15-22, 2010. https://doi.org/10.1590/S0104-77602014000100003

Silva RAF, Setter C, Mazette SS, Melo RR, Stangerlin DM. Colorimetria da madeira de trinta espécies tropicais. Ciência da Madeira (Brazilian Journal of Wood Science), v.8, n.1, p.36-41, 2017. https://doi.org/10.15210/cmad.v8i1.9686

Souza MOA, Silva JDC, Evangelista WV. Aplicação de acabamentos superficiais em madeira de Eucalyptus camaldulensis e Eucalyptus urophylla visando ao uso na indústria moveleira. Scientia Forestalis, v.39, n.92, p.403-409, 2011.

Watai LT. Tecnologia básica em acabamentos de madeiras. São Paulo: Instituto de Pesquisas Tecnológicas. 103p. 1995.

Yamamoto K, Kataoka Y, Furuyama Y, Matsuura T, Kiguchi $M$. The effect of irradiation wavelength on the discouration of wood. Mokuzai Gakkaishi, v.53, n.6, p.320-326, 2007. https://doi.org/10.2488/jwrs.53.320

Zenid GJ, Ceccantini GCT. Identificação macroscópica de madeiras. Instituto de Pesquisas Tecnológicas do Estado de São Paulo - IPT, 24p. 2007. 